\title{
Language education in the EU and the US: Paradoxes and parallels
}

\author{
Jill V. Jeffery ${ }^{1}$ D $\cdot$ Catherine van Beuningen ${ }^{2}$ (D)
}

Published online: 1 June 2019

(C) The Author(s) 2019

\begin{abstract}
Across the globe, linguistically heterogeneous populations increasingly define school systems at the same time that developing the ability to communicate cross-culturally is becoming essential for internationalized economies. While these trends seem complimentary, they often appear in paradoxical opposition as represented in the content and execution of nationwide education policies. Given the differing geopolitical contexts within which school systems function, wide variation exists with regard to how policymakers address the challenges of providing language education, including how they frame goals and design programs to align with those goals. Here we present a cross-continental examination of this variation, which reveals parallel tensions among aims for integrating immigrant populations, closing historic achievement gaps, fostering intercultural understanding, and developing multilingual competencies. To consider implications of such paradoxes and parallels in policy foundations, we compare language education in the US and in the EU, focusing on the Netherlands as an illustrative case study.
\end{abstract}

Keywords Language education $\cdot$ Education policy $\cdot$ Language curricula $\cdot$ Multilingual education $\cdot$ Comparative education

Internationally, language education has occupied a central space in policy discussions regarding the need to integrate students from immigrant backgrounds while preparing all youth for participation in globalized economies. Particularly in contexts like the EU and the US that are defined by dynamic immigration patterns and global economies, education systems are increasingly challenged to realign goals to prepare more culturally and linguistically diverse populations for international work and education environments (aiming for mobility) and to hone their intercultural competencies (aiming for inclusion). Across these dynamic educational contexts, the why, the what, and the how of language education have been approached quite differently, with little exploration of variations in approaches to

Jill V. Jeffery

j.v.jeffery@hum.leidenuniv.nl

Catherine van Beuningen

catherine.vanbeuningen@hu.nl

1 Leiden University Centre for Linguistics, Leiden, The Netherlands

2 HU University of Applied Sciences Utrecht, Utrecht, The Netherlands 
designing and executing policies cross-nationally. Accordingly, in this article we compare how the US and the EU have framed language policy; we then trace relationships between policy and practice in one EU country, the Netherlands, known for high levels of multilingualism. The goal of this contextualized analysis is to inform the design of languageeducation policies and programs that are better suited to meet the needs of all students in a multilingual global context.

The Netherlands, where we are situated as language educators and researchers, is of particular interest when considering language education, given its diverse, polyglot population. The Netherlands boasts high levels of cultural and linguistic heterogeneity. Regarding immigration, $22 \%$ of the Dutch population has an immigration background (CBS 2016), and in the biggest cities (i.e., Amsterdam, Rotterdam, The Hague, Utrecht) this percentage is even higher. In Amsterdam, for example, it is 52\% (Gemeente Amsterdam 2016). The level of multilingualism in the Netherlands is amongst the highest in Europe: a large majority of Dutch citizens (94\%) report being able to speak at least one language in addition to their mother tongue (L1), and 77\% are able to communicate in at least two additional languages (L2 and L3) (European Commission 2012). Moreover, the country's small size makes more salient the need to prepare youth to communicate across cultural and linguistic boundaries in globally competitive economic and educational environments, in which English has become increasingly important. For example, despite some resistance to the growth of English in higher education in the Netherlands and elsewhere (e.g., Bothwell 2016; Huygen 2017), Dutch universities offer an especially high proportion of academic programs in English relative to other European countries (Nuffic 2015a; and Volkskrant reported in 2016 that 60-70\% of courses in the 14 research-oriented Dutch universities were taught in English). Given the intensely multilingual, multicultural context of the Netherlands, its educational system provides a complex case study for examining tensions among a myriad of language-policy imperatives as well as gaps in their implementation.

We first frame our analysis with a long-view comparison of EU and US language policies by examining government documents and relevant scholarship. We then focus in on Dutch language education as implemented within the broader policy framework of the EU, highlighting tensions among policy goals and their realization in curricular approaches. We conclude with a discussion of the parallels and paradoxes highlighted in our comparative analysis and implications for language-education policy globally.

\section{Multilingual education in the EU and the US: Policy and practice}

\section{Education policy}

A fundamental difference between approaches to language education in the EU and the US is the extent to which multiple languages are included in specified outcomes. While EU frameworks include both "mother tongue" (L1) and foreign language (L2 and L3) targets, US policies have not emphasized development of languages other than English, despite increasing globalization. In one EU policy document this foundational difference is highlighted as linguistic heterogeneity is positioned in contrast with the clichéd melting pot metaphor for American assimilation: 
It is this diversity that makes the European Union what it is: not a "melting pot" in which differences are rendered down, but a common home in which diversity is celebrated, and where our many mother tongues are a source of wealth and a bridge to greater solidarity and mutual understanding. (CEC 2005)

Yet, the second, contrasting metaphor-the bridge to greater solidarity-represents EU linguistic diversity in inclusive terms that, paradoxically, parallel the thread that bonds metaphor for the generally monolingual US language policy, which we discuss in greater detail below. In terms of specific policy goals, multilingualism is emphasized across EU position statements. For example, Article 22 of the Charter of Fundamental Rights of the European Union states, "The Union shall respect cultural, religious and linguistic diversity" (Official Journal EC 2000). This Article serves as the basis for EU policies that set trilingualism as a goal for every citizen: in the 2002 meeting of the European Council, it was determined everyone should learn two foreign languages (FLs) in addition to the L1. The EU tracks progress toward such goals through assessments and surveys facilitated by the European Commission (British Council 2013). Using language that directly connects language diversity ( $a$ source of wealth) and inclusiveness (a bridge), EU policies stand in contrast to the US policies that valorize English (a thread that bonds) and that do not emphasize multilingualism.

Adding further coherence to language policy across member states, standards for L2 and L3 development are provided within the Common European Framework of Reference (CEFR) (Council of Europe 2001), which was recently revised (Council of Europe 2017) to address criticisms regarding its lack of empirical basis (e.g., Alderson 2007). The levels and descriptions have long been widely used in language curricula as well as in immigration and employment criteria across Europe. For example, immigrants to the Netherlands must pass a test (Basic Civic Integration Examination, https://www.naarn ederland.nl/en/the-exam) in oral Dutch (CEFR A1 level) and basic writing (A1 level), while still in their home country. Within three years after their immigration, newcomers need to pass a Dutch exam (https://inburgeren.nl/en/taking-an-exam.jsp) that demonstrates a CEFR A2 proficiency level in all language skills (i.e., listening, speaking, reading, and writing).

The EU appears to be approaching this vision of a trilingual citizenry: currently more than half of its citizens are able to converse in at least two languages. However, it is doubtful that this goal has been achieved as a result of EU policy based in valuing language diversity; this outcome has, arguably, resulted largely from the growth of English, the most widely spoken FL in the EU (European Commission 2012). Further, even the high rates of English competence cannot be directly traced to educational programs designed to achieve policy goals, since the extent to which English learning can be attributed to formal education - as compared to population mobility, media exposure, or other factors-remains unclear. For example, regarding English competency in the Netherlands, Verspoor, de Bot, and Xu (2015) explain:

Although the Dutch educational system is known for producing high levels of proficiency in especially English, there is in fact very little empirical support for crediting these results to the educational system. Instead, most studies attribute these results to the relative ease with which English can be acquired through exposure outside school, mainly through the media (cf. Bonnet, 2002). Students are 
motivated to learn English as it is an important international language, and it has a prominent place in the Dutch society, educational system, and scientific world. (p. 6)

Such conclusions suggest paradoxical relationships between the putative intent of EU policy: achieving greater cross-cultural communication through linguistic heterogeneity-and a significant force through which multilingualism is being achieved: homogenizing use of English as an international language.

The use of English as an international language (EIL) also has implications for language education in the US, as it bolsters the case for monolingual tendencies there. For example, the economist and former Harvard University president Larry Summers has argued that the worldwide dominance of English makes it "less clear that the substantial investment necessary to speak a foreign tongue is universally worthwhile" (Summers 2012). In line with this stance, US language policies functionally support English-only curricula (Gutiérrez, Baquedano-López, and Asato 2000) by foregrounding the role of English as a homogenizing force for social integration in federal and state language-education policies. Though this stance provides a clear contrast to the EU values for multilingualism found in policy positions, a closer examination of how policy is enacted in educational programing suggests that, at least in some European contexts, there may be similarities with regard to the prioritization of English education.

In the US, a majority of states (31/50) currently have language policies that grant official status to English in domains such as education and law (Liu, Sokhey, Kennedy, and Miller 2014). On the federal level, although English is not the official language of the US, attempts have been made to make it so and also to limit the use of languages other than English. The most recent attempt, the English Language Unity Act, seeks "to declare English as the official language of the United States, to establish a uniform English language rule for naturalization, and to avoid misconstructions of the English language texts of the laws of the United States" (US Congress 2017). Introduced in the US House of Representatives in February 2017, it is not currently federal law; and, should it become law, it would not officially apply to language education, although it would lend support to statewide policies that limit access to multilingual education. In an echo of the EU bridge metaphor, the Act is framed in positive, inclusive terms by presenting English as a common thread binding individuals rather than as a vehicle for exclusion:

(1) The United States is comprised of individuals from diverse ethnic, cultural, and linguistic backgrounds, and continues to benefit from this rich diversity.

(2) Throughout the history of the United States, the common thread binding individuals of differing backgrounds has been the English language.

(3) Among the powers reserved to the States respectively is the power to establish the English language as the official language of the respective States... (US Congress 2017)

This US proposal parallels EU policy by framing diversity as a cultural resource, but its major premise results in an opposing emphasis: in the EU, language diversity is to be both preserved and further developed; while, in the US, English is needed as the thread that facilitates diversity. This state of affairs suggests a paradox in the role of EIL in which, regardless of policy emphasis, it functions to diminish language diversity. In both the US and the EU, English is positioned as a common language connecting speakers of diverse 
L1s in differing geopolitical contexts, often at the expense of regional and minority languages.

The positioning of English as social integrator is also evident in current US law regarding language education, which requires states to address "limited English proficient" or "English learner" (EL) students' need to develop English but does not require any form of multilingual development in achieving this aim. The Every Student Succeeds Act (ESSA) - an Obama administration amendment of civil rights law guiding funding for public education-includes Title III, the English Language Acquisition, Language Enhancement, and Academic Achievement Act. Broadly speaking, ESSA focuses on closing "achievement gaps" and Title III frames this priority in terms of differences between L1 and L2 English speakers. The first purpose listed in Title III is "to help insure that English learners, including immigrant children and youth, attain English proficiency and develop high levels of academic achievement in English". Further emphasizing the homogenizing role of English, the second purpose stipulates the goal that ELs should succeed in meeting "the same challenging State academic standards that all children are expected to meet" (Purposes 3-5 prescribe support for EL's school staff (3-4) and families (5); US DoE 2017). Since the US has no national educational standards, it is not clear what is meant by "challenging standards". States are required by federal law to measure student progress toward English language and math standards. Historically, states have developed these individually, but, recently, the Common Core State Standards (CCSS) were adopted in a majority of US states after the Obama administration tied federal education funding to their implementation. The CCSS do not include multilingual standards, and as of the writing of this article, we could find no US states that require students to develop proficiency in languages other than English. Thus, federal education policy, as implemented by states, does not require, nor does it necessarily exclude, multilingual education.

\section{From policy to practice in the US}

In practice, the instructional programs employed for carrying out US policy aims are left to states and local school districts, which can and do interpret them broadly to include or exclude minority- and foreign-language education (Johnson 2009). For example, with respect to regional heritage languages such as L1 Spanish in US border states (e.g., Texas), bilingual education, mirroring the ESSA logic, has been viewed primarily in a facilitative role for English-language development. To this end, newcomers are typically placed into sheltered ESL (English as a Second Language) classes, and then transferred into Englishonly instruction. Some border states (e.g., Arizona, California) have explicitly sought to limit bilingual-education programs through controversial policy initiatives (e.g., Proposition 203, 2000) while in one border state, New Mexico, access to L1 Spanish bilingual education has been historically protected. In other areas that are known for cosmopolitanism, diverse immigration patterns, and linguistic heterogeneity, bilingual-education programs are increasingly offered in public school systems. For example, New York City offers bilingual education in L1s that reflect immigration demographics, including, for example, Spanish, Chinese, Haitian Creole, and Arabic, typically with English as the L2 target. Though there are signs of a growing commitment to expanding such programs in large cities like New York (NYC DoE 2016), the availability of bilingual-education programs remains exceptional, politically charged, and highly varied across regions.

With regard to how educational programs designed to implement language policy are funded, we also identified cross-continental parallels, as the EU and the US share a 
tendency to misalign policy and funding for minority- and regional-language education in particular. For instance, though in both contexts protections are granted to endangered languages, these are not always realized in practice. In the EU, the 1992 European Charter for Regional or Minority Languages (Council of Europe 1992) guaranteed educational rights to speakers of endangered and regional languages, and this policy was reinforced in the 2008 Council Resolution on a European Strategy for Multilingualism (CEC 2008). As an example, in theory at least, EU policy legally guarantees Frisian-language education in the northern Dutch province of Friesland. In practice, however, the use of Frisian continues to decline, despite the implementation of a variety of education programs (Gorter 2008; Gorter and Cenoz 2011). Approaches to maintaining Frisian include bilingual (Frisian, Dutch) and trilingual (Frisian, Dutch, English) education programs; however, these have had limited success in halting attrition in Frisian due to a dearth of available Frisian teachers, the rising emphasis on English in Dutch schools, somewhat weak motivation among parents and students for developing academic Frisian as compared to English, and lack of financial support (Gorter and Cenoz 2011). In addition to further illustrating the homogenizing influence of English, this situation points to misalignment between stated EU policy ideals, local aims, and availability of financial resources for implementation.

Similarly, in the US, indigenous languages are legally protected under the Native American Languages Act of 1990, which established that "it is the policy of the United States to preserve, protect, and promote the rights and freedom of Native Americans to use, practice, and develop Native American languages" (US Congress 2000). However, as noted in one of a series of amendments to the Act that were designed to address its lack of funding, "although this was an important step towards assuring the preservation and revitalization of Native American languages, the Act did not dedicate any financial resources to the effort" (US Congress 2000). The education of Native American youth with the goal of preserving indigenous languages remains a challenge, and, like the case of Frisian in the Netherlands, the reported use of indigenous languages among younger as opposed to older Native Americans continues to rapidly decline (US Census 2011).

\section{From policy to practice in the EU: The case of the Netherlands}

To further examine the relationships between language policy and practice in Europe, we turn our attention to the Netherlands, which, given the language profile discussed earlier, would seem to represent a case study for successful achievement of EU targets. However, as we illustrate, trilingualism has often been narrowly interpreted there in ways that, somewhat paradoxically, highlight parallels between the EU and the US. To orient readers, we first provide a brief overview of the social context within which language curricula are conceptualized in the Netherlands, including immigration patterns and related policy shifts. Then, after providing a quick structural overview of Dutch school systems, we focus on how language policies are being implemented in two dominant educational frameworks (communicative foreign language teaching, and programs that integrate content and language learning).

Dutch policy regarding the goal and role of bilingual education has evolved historically alongside changing immigration and socioeconomic interests in the Netherlands. As detailed by Driessen (2000), prior to the 1980s, the "two-track" approach assumed that the children of migrant guest workers, many of whom immigrated from Mediterranean countries in the 1960s, would not remain in the Netherlands. Thus, the early rationale for 
bilingual education was that L1 language maintenance was important for students' reintegration to their origin countries. As it became clear that the students would remain, the rationale shifted. In the 1980s, the rationale for education in L1 minority languages was reframed in terms of integration-as a means of bridging achievement gaps between L1/ minority and L2/majority language proficiency. During this period, bilingual programs and their aims became marginalized as L1 language maintenance was no longer seen as the responsibility of the Dutch government. Glastra and Schedler (2004) explain how, during this period, Dutch government policy

stated that the question of whether minority pupils would benefit from learning their own language in second language acquisition was at least controversial. It advised that education in languages and cultures of origin, the attendance of which was on a voluntary basis, should no longer be part of the regular curriculum. Instead, it urged for special attention with regard to instruction in Dutch as a second language ... (p. 47)

In practice, schools offered-often, outside school hours-onderwijs in eigen taal en cultuur [education in own language and culture], which evolved in the 1990s to onderwijs in allochtone levende talen [education in allochthonous living languages]. Another rationale offered for minority L1 education, also related to the goal of integration, was to enhance students' sense of cultural identity through "intercultural education". In practice, however, most students were unlikely to receive viable instruction in their L1 regardless of which rationale was offered because instruction was typically available only in standard varieties that students did not speak (e.g., standard Arabic rather than Berber).

Ultimately, this type of bilingual education for immigrant students was abandoned altogether in 2004 for a combination of reasons, including a lack of available teachers to match the L1 minority languages, political debates regarding which minority languages should be taught, and lack of financial support (Kuiken and Van der Linden 2013). The argument for cancelling the funding of minority L1 programs was that education in immigrant languages contradicted the goal of integrating immigrant youth (Extra and Yağmur 2006). Kuiken and Van der Linden (2013) observe that this policy shift "flies in the face of European directives to promote a multilingual society where European citizens master two other languages besides their native tongue" (p. 213). Though immigrant youth are often already proficient in speaking more than one language, language-education programs have positioned minority L1s not as platforms for multilingual development but as, at best, bridges to learning Dutch.

Currently, in practice, the EU goal that each citizen should speak three languages is generally interpreted in Dutch curricula as Dutch plus two "big" European languages, particularly, English plus French or German. As Verspoor and Cremer (2008) demonstrate in their review of Dutch FL-education scholarship, "[T]here is only government financing of second-language education if this concerns education in the European languages. Although the Dutch government stresses that all immigrant languages be respected, state support is no longer given" (p. 185). This state of affairs points to a larger pattern wherein language policy goals and guidelines are provided but, at least when it comes to minority- and heritage-language education, these are not supported with funding.

Further contributing to the diminished role of minority and heritage bilingual education in the Netherlands is the growth of English, which replaced French as the dominant L2 in the early twentieth century (Wilhelm 2005). English no longer even truly functions as an FL in the Netherlands (Edwards 2016), since a large majority (90\%) of Dutch citizens claim proficiency (European Commission 2012), and English is one 
of three required subjects in Dutch public school curricula (the others are mathematics and Dutch). Accordingly, we use "FL" in the Dutch context to refer to foreign languages other than, or in addition to, English. Whereas instruction in FLs is generally deferred until secondary school, students typically begin receiving instruction in English in later primary school, and all students continue English classes throughout secondary school. Increasingly, however, Dutch primary schools are offering English in even earlier grades in the form of either VVTO [vroeg vreemdetalenonderwijs; or, "early foreign language education"] or even TPO [tweetalig primair onderwijs; or, "bilingual primary education"] in which $30-50 \%$ of the curriculum is offered in English. Such bilingual programs are even more common at the secondary level.

Language-education requirements vary depending on which of three vocational or pre-university tracks students are sorted into at the end of primary school (approximately age 12) (Figure 1). In theory, all students have equal opportunity to transfer to the pre-university education streams, but in practice immigrant students with a nonWestern background continue to be overrepresented in the vocational tracks $(20 \%$ of all secondary students from non-Western immigrant backgrounds undertake this track, compared to $9 \%$ of all students from non-immigrant backgrounds) and underrepresented in the university tracks (13\% of students from non-Western immigrant backgrounds

Figure 1 Basic Structure of the Dutch Education System Source: Nuffic (2015b).

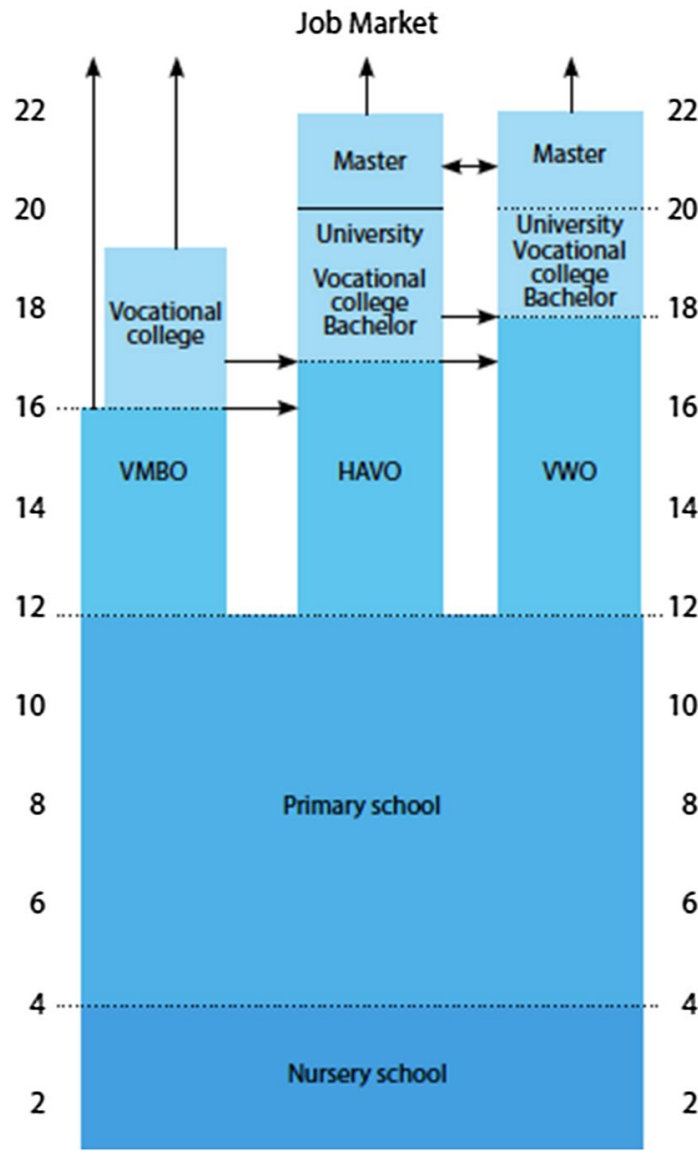


compared to $23 \%$ of students with non-immigrant backgrounds) (CBS 2016). Thus, the varying language-education criteria across tracks, combined with the dearth of programs in minority L1s, differentially affect the language-education opportunities of students from immigrant backgrounds.

All students are required to study English throughout secondary education, but requirements for additional FLs vary depending on the track into which students are sorted. All secondary students must study at least one FL, usually German or French. Students in vocational tracks (VMBO, cf. Figure 1) are required to study one FL for the first two years, while students in the HAVO and VWO (cf. Figure 1) stream must study two FLs for the first three years. English is compulsory in the higher grades of every track for qualifying examinations; VWO students must also take exams in one additional FL. In addition to German and French, qualifying examinations exist for Spanish, Russian, Arabic, and Turkish; however, especially as regards the latter two languages, such programs are quite rare. In 2017, only 77 pupils took final examinations in Arabic, and 178 in Turkish (SLO 2017). Again, pointing to a misalignment between policy and material support, Benedictus-van den Berg suggests the reason for these low numbers is weak government funding, and observes that the "low uptake of Turkish and Arabic is all the more noteworthy given the increase in the number of Turkish-Dutch and Moroccan-Dutch children in primary schools in urban areas" (Extra and Yağmur 2012, p. 165).

\section{CLT approaches}

Models that Dutch schools adopt for the delivery of FL instruction (including English) vary, but the two most prominent are the "traditional" Communicative Language Teaching (CLT) approach, in which the FL is only the target of instruction, and the bilingual Content- and Language-Integrated Learning approach (CLIL), in which the FL functions as both instructional goal and medium. Most Dutch secondary schools adopt a CLT approach by offering language subjects (e.g., courses in English, French, German) in which the main focus is on the development of target-language proficiency. Required learning outcomes are formulated in terms of communicative acts (e.g., de kandidaat kan adequaat reageren in sociale contacten met doeltaalgebruikers [the candidate can react adequately in social contact with users of the target language] or de kandidaat kan informatie vragen en verstrekken [the candidate can ask for or provide information]) (College voor Toetsen en Examens 2016, p. 26). Key principles of the CLT approach include a focus on meaningful communication and ample opportunity for authentic use of the target language through interaction (Canale and Swain 1980; Richards 2006). Expected proficiency levels are specified in relation to the CEFR, for every educational track, target language, and language skill (i.e., listening, speaking, reading, writing).

Even though CLT approaches to language teaching are an internationally accepted standard in Europe, and Dutch national curricular documents are framed according to CLT principles, in reality in many Dutch classrooms the focus is not so much on teaching students to communicate effectively but, rather, on grammatical forms and accuracy (Kwakernaak 2016; West and Verspoor 2016). Another challenge lies in the way language education makes use of and builds on students' multilingual competencies. In current curricula, the multilingual repertoires students bring to the classroom are often ignored, and hardly ever appealed to purposively. This holds for both the L1 competencies of minority students and for students' knowledge of and skills in languages taught at school (i.e., other FLs). 
By adopting this fragmented approach, Dutch language-education often neglects to take advantage of valuable opportunities for exploiting linguistic competencies that could function as scaffolds for the learning of a target language (e.g., Cummins 2007).

A third challenge concerns the content of CLT. In current classrooms, common topics students are invited to communicate about are things like holidays or hobbies. Even though the use of such topics may lead to authentic communication, there has been a recent call for more meaningful content in language classes by expert bodies in the field, such as the Meesterschapsteam Moderne Vreemde Talen [Mastery Team Modern Foreign Languages] (Meesterschapsteam Moderne Vreemde Talen 2016; Tammenga-Helmantel and Le Bruyn 2016). Both linguistic and cultural subject matter could make valuable additions to language curricula. A greater focus on linguistic (e.g., sociolinguistic issues, language-learning theories) and cultural content (e.g., literature, customs, and traditions of the target-language country) could foster students' language awareness (Van den Broek and Dielemans 2017) and also contribute to the development of intercultural competencies (Karmanova and Van Loo 2016).

\section{The CLIL model}

Bilingual education remains a controversial issue in the Netherlands. However, since the late 1980s, bilingual programs that focus on European FL targets with Dutch as the L1 have rapidly expanded, and Tweetalig Onderwijs (TTO) [bilingual education] is becoming more prominent in the Dutch education system as English continues to gain traction. Bilingual education has seen a rapid growth, both in the number of schools offering bilingual programs, as well as in the breadth of educational tracks in which it is implemented. Currently, around $20 \%$ of Dutch secondary schools offer bilingual streams; and, whereas at first bilingual programs were exclusively offered in pre-university tracks, today bilingual routes are also available at the pre-vocational level and are also being piloted in Dutch primary schools (Denman, Tanner, and De Graaff 2013; Mearns, De Graaff, and Coyle 2017). Consistent with the growth of EIL, there has been a sharp increase in Dutch-English bilingual education programs on the secondary level (Kuiken and Van der Linden 2013), and practically all bilingual tracks in the Netherlands are now offered in Dutch-English. Although Dutch-German programs do exist in schools close to the German border, these are very rare.

An approach to bilingual education that is quickly growing in Western European countries is that of Content- and Language-Integrated Learning, or CLIL (Verspoor et al. 2015), discussed above, which arose in the 1980s as bilingual programs emphasizing minority L1s were generally abandoned. CLIL is "an educational approach where curricular content is taught through the medium of a foreign language, typically to students participating in some form of mainstream education at the primary, secondary, or tertiary level" (DaltonPuffer 2011, p. 183). CLIL programs thus aim to develop both students' L2 proficiency and their content knowledge, by teaching non-language subjects (e.g., geography) in the target language. The target language thereby becomes both the object of learning and the medium in and through which content learning takes place. In Dutch secondary-level CLIL programs, at least $50 \%$ of the curriculum has to be taught in the L2 target language. The Standard for Bilingual Education (Nuffic 2012), which is endorsed by all Dutch schools that are members of the national network for bilingual education, specifies the basic requirements that TTO schools need to meet, in terms of L2 attainment levels, quantity and quality of L2 input, levels of content knowledge, European and International Orientation (EIO) skills, 
and quality control (e.g., obligatory assessment/accreditation trajectories). Students in such bilingual programs must also pass school-leaving exams in Dutch, and these programs also often include International Baccalaureate and Cambridge English exams as assessments.

Bilingual education in the Netherlands is also, in theory, focused on building intercultural communication skills, or an EIO—standards for which are represented in the Common Framework for Europe Competence (CFEC) (Elos 2010) and are aligned to the CEFR. For example, at the highest level (6) for communication, a student "can discuss controversial international issues with people from other backgrounds in a common language, while acknowledging differences in norms and values" (EIO-2.6.2). At level 3 , the designation for a graduate from a pre-university track, a student "can express [his/her] own opinions, needs, feelings and communicate coherently about them in a common language of communication with [his/her] peers from other countries" (EIO2.3.2). The CFEC standards also require students to know about and appreciate different cultures and languages and to acquire the necessary knowledge and skills to collaborate internationally in employment and educational environments.

Although bilingual education in the Netherlands is becoming more inclusive, CLIL tracks are still most prevalent in the "higher" tracks of secondary education. Since socially privileged students are overrepresented in these pre-academic strands, Dutch bilingual education has a reputation of being elitist (Mearns et al. 2017), an impression that is supported by the fact that although TTO programs are implemented in public schools, bilingual education does not receive direct government funding from the Dutch Ministry of Education, Culture and Science. Parents of students in TTO schools pay voluntary tuition fees averaging $€ 450$ per student per year (as compared to the $€ 188$ on average that parents are asked to contribute for activities such as expeditions in Dutch schools), according to a TTO description document (Nuffic 2015b). Thus, bilingual education in the Netherlands is not equally available to all students. The document further explains that "in the first three years of secondary school TTO students are exposed to approximately six times more English in class than their non-TTO peers; not to mention the extracurricular activities" (Nuffic 2015b, p. 6), suggesting vast differences, in not only content but perhaps quality as well (e.g., in relation to the development of students' intercultural competences), between the two educational approaches to language education.

As noted above, and as is made clear in its grounding in EU standards and policies, the CLIL framework is part of a larger European project and is aligned with an EU language policy that sets trilingualism for everyone as a goal. The situation in the US is quite different given the lack of foreign-language requirements in the education system; English-focused language policies at the federal level; the relative dearth of public bilingualeducation programs; and some statewide policies that even restrict access to bilingual education. In the US, minority-language students are labeled in deficient terms as "limited" and, other than in a handful of bilingual programs in metropolitan areas, are offered little, if any, education in a minority L1 as a means of preparing for English-only instruction. Yet, although multilingual education is strongly supported in the Netherlands, like the US, the Dutch education system currently does not focus on building on the language resources that immigrant students bring to the classroom in realizing policy goals. Despite the presence of some language-education programs that include a minority L1, "multilingual" most commonly means being able to speak Dutch and English proficiently and, in some cases, acquire some skills in another FL (typically either German or French), while funding for L1 minority-language education was effectively cut more than a decade ago. Thus, one main difference, in practice, is that a majority of US students already speak the internationally most highly valued language that Dutch students are required to learn-English. 
Moreover, both in the Netherlands and in the US, gaps between policies and resources provided for enacting them persist, and this is especially true for minority-language education-suggesting strong parallels between school systems, despite opposing monolingual (US) and multilingual (EU) policy foundations.

\section{Discussion}

This overview of language policy in the Netherlands, as situated within the context of the EU and as compared to the US, highlights the challenges and opportunities involved in designing educational programs around the globe that foster and valorize students' multilingual competencies. We introduced this analysis with the idea that two trends- the increasing linguistic heterogeneity in our schools and the increasing importance of knowing how to use multiple languages within the context of intensifying globalization-would seem to be in harmony with one another. Yet, despite policies in both the Netherlands and the US that praise diversity (if not, in the case of the US, multilingual development), our school systems have not effectively fostered the diverse language practices our students bring to school, including, for many students, multilingual competencies. For example, many immigrant and minority students enter the Dutch system with some proficiency in two or more languages - bringing them closer to the EU goal of a trilingual citizenry. Yet, as in the US, the goals of cultural integration, along with the relatively high status of English as an international language, have driven a pattern in which bilingual education focusing on L1 minority languages has been largely abandoned.

This analysis, therefore, highlights the need to negotiate tensions between goals related to integration and internationalization, or, as framed in the MIME (Mobility and Inclusion in Multilingual Europe) project, the need to "balance the requirements of mobility in a modern, integrated, technologically advanced society with the need to maintain and take advantage of Europe's linguistic and cultural diversity" (MIME 2017). Another way of framing this challenge that highlights similarities between the US and the EU is by considering the importance of building on the L1 language resources that immigrant and language-minority students bring with them to school. Our comparison of the Netherlands and the US suggests that, regardless of differing values regarding language education that are represented in language policies, neither school system is yet committed to this challenge.

This issue has not gone unnoticed by stakeholders in Europe. For example, the Language Rich Europe project has called for tighter linkage between EC language policy and the reality of a linguistically complex European population, particularly as regards trilingualism. Acknowledging the realities that "for many citizens 'mother tongue' is no longer the same as the national language" and that "most citizens will learn English plus one, so it is rarely any "two", the project calls for "the clear articulation of a linguistic profile" (British Council 2013, p. 4). Focusing further on the role of English as an international language, the project calls for new education and research funding structures:

The particular position of English in Europe should be explicitly acknowledged, in order to propose a new model for the co-existence of languages in Europe. This would have implications for policy formulations, in particular the key objective of "mother tongue plus 2". It would also encourage more research and development work on the ways in which the position of English could be used to promote and support multi/plurilingualism rather than to undermine it. Finally it would mean that European funding streams, for example, the successor to the Lifelong Learning Pro- 
gramme, would prioritise support for languages other than English. (British Council 2013, p. 5)

In addition to changes in language policies and standards, the project calls for improved training of language teachers, including international agreements that would facilitate teacher mobility, such as teacher-exchange programs.

One implication of this analysis is that more investment, in terms of funding for teacher training, design of course materials, and structural reorganization, is needed for both Dutch and US school systems to realize their stated policy goals. Across the globe, with few exceptions, language policies remain largely disconnected from practice, with local school districts left holding the bag for implementation, with inadequate financial support and staffing options. To address these issues, richer conceptualizing of and stronger support for teacher training with regard to the interrelated roles of different languages (i.e., L1, L2, FLs) is needed to manage tensions between goals for fostering multilingualism, narrowing opportunity gaps, and integration, through language education across the globe.

Another implication, which forms the framework for the MIME project, is that a more comprehensive approach to language policy is needed, one that acknowledges that complex immigration patterns, expanding globalization, and proliferation of communication technologies have led to "fundamental and rapid change" (MIME 2017). This reshaping of our societies and the language-learning needs it engenders require more comprehensive approaches to policy and curricula that take into account tensions between immigration and internationalization. MIME argues for a "trade-off" framework for re-envisioning language policy:

... a trade-off problem arises between "mobility" and "inclusion". On the one hand, if society were to opt for an exclusive emphasis on the necessities of inclusion in a specific place in the EU, this could lead to material or symbolic impediments to citizens' mobility .... Conversely, an exclusive focus on mobility can have a detrimental effect on inclusion, because it may, through the potentially uniformising forces it abets, erode the sense of place, specificity and rootedness associated with different locales within the EU. (p. 4).

Taking as a starting point the need to frame policy in this way is one path out of the current policy tendencies evident in the analysis we present here. For example, in the Netherlands, prior to the 1980s, bilingual education focused more on inclusion and migration in minority L1-Dutch L2 programs, and then shifted rather abruptly to focus more on mobility and integration in Dutch-English CLIL programs.

A further implication of this policy reframing is the understanding that language education extends beyond formal schooling, and that there are a variety of motivations for language learning that suggest varying approaches. For example, as Verspoor et al. (2015) note, the exceptionally high levels of English proficiency among Dutch students cannot necessarily be traced back to formal English-education programs. Students are motivated to learn English through, for example, participation in international gaming networks, as well as exposure to other English-language media. In addition, immigrant students, through technology tools that allow for greater social connectivity, may have more opportunities than in the past to communicate in and further develop a minority L1. Educational approaches that facilitate out-of-school pathways for developing language skills, and that include helping students to develop goals for language learning, would better align with the reality of the many ways in which youth engage with language across social contexts. The Language Rich Europe project makes some recommendations in this regard. It calls 
for more subtitling (as opposed to dubbing) "to promote the language competencies of citizens and officials in Europe" (British Council 2013, p. 6) as well as for more research into "good practice in Multilingual Communications Modes", including in technology-assisted communication.

Despite differing emphases on multilingualism, these implications hold for both the EU and the US. The attempts to force an English-monolingual policy on a historically heterogeneous population in the US fail to acknowledge the realities of globalization and its increasingly complex communication demands. Even exceptional proficiency in English alone is inadequate to meet these demands. The expansion of EIL requires, at the very least, an understanding of how English is used differently in different international contexts. Students not only need skills-focused instruction but also need to develop the dispositions and flexible understandings of how language use differs across (cultural) contexts. Further, development of minority and immigrant students' L1 language resources, whether facilitated by bilingual, out-of-school, or community-based programs - or a combination of approaches - should be made an explicit policy goal that could, among other benefits, foster intercultural and interlinguistic competence in globally competitive environments where these skills are becoming increasingly important.

Yet, even in EU countries such as the Netherlands, where multilingualism and intercultural communication are made explicit policy goals, a policy reorientation is also needed to translate an appreciation for language diversity into goals regarding immigrant and minority students' L1 language resources. Again, this could involve a combination of approaches, including valorizing students' multilingual repertoires within mainstream (language) education, but also community-based programs that provide resources to facilitate communication with family and other contacts from the country of origin, for example. In fact, a handful of existing private initiatives reflecting this understanding could serve as guides (e.g., Stichting TON extracurricular Turkish education) for more widely available government-funded approaches. It could also involve creating more opportunities for both L1 and L2 Dutch-speaking students to practice and reflect on the challenges and opportunities of intercultural communication across secondary tracks. The envisioned policy reorientation would also require a reframing of the trilingualism ideal, extending it to explicitly include L1 minority languages, both in theory and in practice.

Moreover, this analysis suggests that neither the CLT nor the CLIL approach, as currently practiced in Dutch schools, is entirely effective in achieving larger policy goals. In the absence of policies that aim to foster multilingualism in the broadest sense (including minority languages) and that facilitate the recruitment, training, ongoing professional development, and retaining of high-quality teachers who have the abilities to build on and expand the multilingual repertoires of their students, any language-education approach embraced by a school system is unlikely to achieve the goal of providing students with the flexible, multilingual, cross-cultural skills and dispositions they need for an internationalized language environment.

Open Access This article is distributed under the terms of the Creative Commons Attribution 4.0 International License (http://creativecommons.org/licenses/by/4.0/), which permits unrestricted use, distribution, and reproduction in any medium, provided you give appropriate credit to the original author(s) and the source, provide a link to the Creative Commons license, and indicate if changes were made. 


\section{References}

Alderson, J. C. (2007). The CEFR and the need for more research. Modern Language Journal, 91, 659-663.

Bonnet, G. (Ed.) (2002). The assessment of pupils' skills in English in eight European countries. Paris: European Network of Policy Makers for the Evaluation of Education Systems.

Bothwell, E. (2016). Dutch debate growth of instruction in English. Inside Higher Ed (8 September). https ://www.insidehighered.com/news/2016/09/08/dutch-educators-debate-growth-english-instruction-their -universities

British Council (2013). Language rich Europe: Multilingualism for stable and prosperous societies. https:// www.britishcouncil.nl/sites/default/files/lre_review_and_recommendations.pdf.

Canale, M., \& Swain, M. (1980). Theoretical bases of communicative approaches to second language teaching and testing. Applied Linguistics, 1, 1-47.

CBS [Centraal Bureau voor de Statistiek] (2016). Bevolking naar migratieachtergrond [Population classified by migration background]. https://www.cbs.nl/nl-nl/achtergrond/2016/47/bevolking-naarmigratieachtergrond. For more information on Dutch school system demographics, see this source at https://opendata.cbs.nl/statline/\#/CBS/nl/dataset/80040NED/table?ts=1552991379077.

CEC [Commission of the European Communities] (2005). A new framework strategy for multilingualism. http://eur-lex.europa.eu/LexUriServ/LexUriServ.do?uri=COM:2005:0596:FIN:en:PDF.

CEC (2008). Multilingualism: An asset for Europe and a shared commitment. http://www.europ arl.europa.eu/RegData/docs_autres_institutions/commission_europeenne/com/2008/0566/ COM_COM(2008)0566_EN.pdf.

College voor Toetsen en Examens (2016). Moderne vreemde talen havo [Modern foreign languages havo]. Version 2 (June). Utrecht: College voor Toetsen en Examens. https://www.examenblad.nl/examenstof/ syllabus-2018-moderne-vreemde/2018/f=/moderne_vreemde_talen_havo_2_versie_2018.pdf.

Council of Europe (1992). European charter for regional or minority languages. https://www.coe.int/en/ web/conventions/full-list/-/conventions/rms/0900001680695175.

Council of Europe (2001). Common European reference for languages: Learning, teaching, assessment. Cambridge: Cambridge University Press.

Council of Europe (2017). Common European framework of reference for languages: Learning, assessment. https://rm.coe.int/common-european-framework-of-reference-for-languages-learning-teach ing/168074a4e2.

Cummins, J. (2007). Rethinking monolingual instructional strategies in multilingual classrooms. Canadian Journal of Applied Linguistics, 10, 221-240.

Dalton-Puffer, C. (2011). Content-and-Language Integrated Learning: From practice to principles? Annual Review of Applied Linguistics, 31, 182-204.

Denman, J., Tanner, R., \& de Graaff, R. (2013). CLIL in junior vocational secondary education: Challenges and opportunities for teaching and learning. International Journal of Bilingual Education and Bilingualism, 16, 285-300.

Driessen, G. (2000). The limits of educational policy and practice? The case of ethnic minorities in the Netherlands. Comparative Education, 36, 55-72.

Edwards, A. (2016). English in the Netherlands: Functions, forms and attitudes. Amsterdam: John Benjamins.

Elos (2010). Common framework for Europe Competence. Lifelong Learning Programme. Published by the European Elos Network of the European Union. http://www.tallinn.ee/haridus/Common-Frame work-for-Europe-Competence-ELOS-students-.pdf.

European Commission (2012). Special Eurobarometer 386: Europeans and their languages. Report conducted by TNS Opinion and Social at the request of Directorate-General Education and Culture, Directorate-General for Translation and Directorate-General for Interpretation. http://ec.europa.eu/ commfrontoffice/publicopinion/archives/ebs/ebs_386_en.pdf.

Extra, G., \& Yağmur, K. (2006). Immigrant minority languages at home and at school: A case study of the Netherlands. European Education, 38, 50-63. https://doi.org/10.2753/EUE1056-4934380204.

Extra, G., \& Yağmur, K. (Eds.) (2012). Language rich Europe: Trends in policies and practices for multilingualism in Europe. Cambridge: Cambridge University Press. https://englishagenda.britishcou ncil.org/sites/default/files/attachments/lre_english_version_final_01.pdf.

Gemeente Amsterdam (2016). Trendanalyse: Diversiteit van de Amsterdamse bevolking [Trends analysis: Diversity in the Amsterdam population]. Onderzoek, Informatie en Statistiek (27 September). https://www.ois.amsterdam.nl/nieuwsarchief/2016/diversiteit-in-de-stad-neemt-toe.

Glastra, F. J., \& Schedler, P. E. (2004). The language of newcomers: Developments in Dutch citizenship education. Intercultural Education, 15, 45-57. 
Gorter, D. (2008). Developing a policy for teaching a minority language: The case of Frisian. Current Issues in Language Planning, 9, 501-520.

Gorter, D., \& Cenoz, J. (2011). Multilingual education for European minority languages: The Basque Country and Friesland. International Review of Education, 57, 651-666.

Gutiérrez, K. D., Baquedano-López, P., \& Asato, J. (2000). "English for the children": The new literacy of the old world order, language policy and educational reform. Bilingual Research Journal, 24, 87-112.

Huygen, F. (2017). Opinie: Engels als voertaal vernielt het hoger onderwijs [Opinion: English as the language of instruction destroys higher education]. Volkskrant (28 June). https://www.volkskrant .nl/columns-opinie/opinie-engels-als-voertaal-vernielt-het-hoger-onderwijs $\sim \mathrm{b} 7 \mathrm{fd} 8359 /$.

Johnson, D. C. (2009). Ethnography of language policy. Language Policy, 8, 139-159.

Karmanova, O., \& Van Loo, E. (2016). Interculturele competentie in de taalles: Een Korte Lessenserie Russisch [Intercultural competence in language lessons: A short Russian lession series]. Levende Talen Magazine, 5, 22-27.

Kuiken, F., \& van der Linden, E. (2013). Language policy and language education in the Netherlands and Romania. Dutch Journal of Applied Linguistics, 2, 205-223.

Kwakernaak, E. (2016). Kennis over talen en culturen [Knowledge of languages and cultures]. Levende Talen Magazine, 7, 28-32.

Liu, A. H., Sokhey, A. E., Kennedy, J. B., \& Miller, A. (2014). Immigrant threat and national salience: Understanding the "English official" movement in the United States. Research and Politics, 1, 1-8.

Mearns, T., de Graaff, R., \& Coyle, D. (2017). Motivation for or from bilingual education? A comparative study of learner views in the Netherlands. International Journal of Bilingual Education and Bilingualism. https://doi.org/10.1080/13670050.2017.1405906.

Meesterschapsteam Moderne Vreemde Talen (2016). Betekenisvol vreemde-taalonderwijs en implicaties voor vakdidactisch onderzoek [Meaningful foreign language education and implications for didactic research]. Valdidacktiek geesteswetenschappen (September). https://vakdidactiekgw.nl/wp-content/ uploads/2016/09/discussietekst-MVT-september-2016-met-logo.pdf.

MIME [Mobility and Inclusion in Multilingual Europe] (2017). The multilingual challenge: Toward policy responses. Geneva: University of Geneva. http://www.mime-project.org/MIME_TheMultilingualChall enge_150317.pdf.

Nuffic (2012). Standard for bilingual education in English-havo/vwo. https://www.nuffic.nl/en/publicatio ns/standard-bilingual-education/.

Nuffic (2015a). Key figures 2015: Internationalization in higher education. The Hague: EP-Nuffic. https:// www.studyinholland.nl/documentation/key-figures-2015-internationalisation-in-higher-education.pdf.

Nuffic (2015b). Bilingual education in Dutch schools: A success story. https://www.nuffic.nl/en/publicatio ns/bilingual-education-dutch-schools-success-story/.

NYC DoE [Department of Education] (2016). Chancellor Fariña announces 38 new bilingual programs. https://www.schools.nyc.gov/about-us/news/announcements/contentdetails/2016/04/04/chancellor -fariña-announces-38-new-bilingual-programs.

Official Journal EC [Official Journal of the European Communities] (2000). Charter of fundamental rights of the European Union. European Parliament. http://www.europarl.europa.eu/charter/pdf/text_en.pdf.

Proposition 203 (2000). English language education for children in public schools. https://cms.azed.gov/ home/GetDocumentFile?id=58d003651130c012d8e906e5.

Richards, J. C. (2006). Communicative language teaching today. New York: Cambridge University Press.

SLO [Stichting Leerplanontwikkeling] (2017). Moderne vreemde talen [Modern foreign languages]. https:// slo.nl/vakportalen/mvt/.

Summers, L. H. (2012). What you (really) need to know. New York Times (20 January). http://www.nytim es.com/2012/01/22/education/edlife/the-21st-century-education.html?pagewanted=all.

Tammenga-Helmantel, M., \& Le Bruyn, B. (2016). Mvt-onderwijs: Hoe willen we het hebben en wat willen we weten? [Foreign language education: How do we want it and what do we want to know?]. Levende Talen Magazine, 8, 44-45.

US Census (2011). Native North American languages spoken at home in the United States and Puerto Rico: 2006-2010. https://www.census.gov/library/publications/2011/acs/acsbr10-10.html.

US Congress (2000). Amending the Native American Languages Act to provide for the support of Native American language survival schools, and for other purposes. Report, Committee on Indian Affairs (3 October). https://www.congress.gov/106/crpt/srpt467/CRPT-106srpt467.pdf.

US Congress (2017). HR 997: English Language Unity Act of 2017. Introduced 9 February. https://www. congress.gov/bill/115th-congress/house-bill/997/text.

US DoE [Department of Education] (2017). Elementary and Secondary Education Act of 1965 as amended by the Every Student Succeeds Act. Enacted 21 July 2018. https://legcounsel.house.gov/Comps/Eleme ntary\%20And\%20Secondary\%20Education\%20Act\%200f\%201965.pdf. 
Van den Broek, E., \& Dielemans, R. (2017). Bewuste taalvaardigheid in de klas [Language awareness skills in the classroom]. Levende Talen Magazine, 4, 12-16.

Verspoor, M., \& Cremer, M. (2008). Research on foreign-language teaching and learning in the Netherlands (2002-2006). Language Teaching, 41, 183-211.

Verspoor, M., de Bot, K., \& Xu, X. (2015). The effects of bilingual education in the Netherlands. Journal of Immersion and Content-Based Language Education, 3, 4-27. https://doi.org/10.1075/jicb.3.1.01ver.

West, L., \& Verspoor, M. (2016). An impression of foreign language teaching in the Netherlands. Levende Talen Tijdschrift, 17, 26-36.

Wilhelm, F. A. (2005). English in the Netherlands: A history of foreign language teaching 1800-1920 with a bibliography of textbooks. PhD dissertation. Radboud Universiteit, Nijmegen.

Publisher's Note Springer Nature remains neutral with regard to jurisdictional claims in published maps and institutional affiliations.

Jill V. Jeffery (the Netherlands) is an associate professor at Leiden University Centre for Linguistics. Her scholarship, which focuses on the teaching, learning, assessment, and development of writing in secondary school settings, draws from social-constructivist theories that emphasize the role of authorial agency in learning to write. Prior to her coming to Europe in 2016, her work primarily focused on US policy and practice, beginning with her $\mathrm{PhD}$ dissertation (New York University) regarding voice in written composition, which was supported by a Carnegie fellowship. Her recent work focuses on cross-national comparisons that aim to shed light on how language development might be better supported through innovative policy and research.

Catherine van Beuningen (the Netherlands) has a $\mathrm{PhD}$ in applied linguistics from the University of Amsterdam. Her research interests include instructed second-language learning, second-language writing, the role of feedback in language learning, (language) teaching in multilingual classrooms, and teacher professional development. She currently holds a position of senior researcher within the Research Centre for Learning and Innovation at the HU University of Applied Sciences Utrecht. She also works as a senior lecturer within the Faculty of Education at the Amsterdam University of Applied Sciences. Catherine is a member of the Editorial Board of the Journal of Second Language Writing and editor for the Dutch Journal of Applied Linguistics. 